\title{
Anglican Christians and Modern Political Economy
}

\author{
Salim Rashid
}

Faith is belief in things unseen, while Finance is the bringing of savers and investors together. Since both saving and investing requires some beliefs about the future, there is an obvious sense in which Finance implies faith about law, property, society, and so on. But this connection lacks depth or consequences and seems almost trivial. The more common connotation of faith involves the holding of distant views which motivate lifelong activity-while stocks and bonds can be instruments in such a life, finance must have a larger vision to accompany such faith. Ending poverty implies the diffusion of plenty among a people and economic growth is essential for the spread of plenty. ${ }^{l}$ Growth requires investment, which in turn is possible with saving. Since the meeting of savers and investors defines finance, a more promising approach is to ask how faith has contributed

${ }^{1}$ As opposed to a simple redistribution of existing wealth, always the Easiest way of achieving equality of possessions.

\author{
S. Rashid ( $\bowtie)$ \\ Emeritus Professor, Department of Economics, University of Illinois-Urbana \\ Champaign, Urbana, IL, USA \\ e-mail: srashid@illinois.edu \\ University Professor, East West University, Dhaka, Bangladesh \\ (C) The Author(s) 2020 \\ T. Akram and S. Rashid (eds.), Faith, Finance, and Economy, \\ https://doi.org/10.1007/978-3-030-38784-6_6
}


to those forms of finance which enable growth with equity-to that economic growth which diffuses plenty.

That Christianity is the backbone of European economic growth has long been a thesis of mine. ${ }^{2}$ Since economies function well only when ensconced within supportive societies, any hypotheses about the influence of religion on society, and vice versa, has to relate the economy to society independently of religion. What societal beliefs are central to a well-functioning market economy? There are five forms of faith that are essential for markets to flourish. As a mnemonic, they are called 'ethics' below:

1. Legal ethic or the rule of law

2. Consumption ethic or the fitness of commodities

3 . Work ethic or the rightness of effort

4. Knowledge ethic or the glory of knowing

5. Support ethic or the unconditionality of social bonds.

Showing how and why Christianity was an essential part, sometimes a driving force, in each 'ethic' between 1000 and 1800 requires lengthy arguments. Social change typically involves multiple proximate causes. Tracing each such cause back to its Christian impetus, even when possible, involves long, complex arguments. Furthermore, since Christians themselves freely acknowledged their debts to the Hellenes and the Romans, separating the roots is almost impossible. ${ }^{3}$ Some of the proofs are easy, as in showing the widespread prevalence of the support ethic, encouraged and institutionalized by Christianity, through the ages. Evidence for some others, such as the rule of law, become manageable once we look for the right evidence-not necessarily in the lawbooks, but in the lives

${ }^{2}$ That Christianity has been an essential pillar of Western civilization has been argued by many, as my references to Herbert Butterfield and Christopher Dawson will illustrate. The topic has been argued more recently by such authors as Rodney Stark. Supporting this general proposition through specifically economic arguments appears to be new. The focus upon Markets and Christian theology by authors, such as Geoffrey Brennan and A. M. C. Waterman, is entirely different. David Rose's highly acclaimed book on The Moral Foundation of Economic Behavior (Oxford 2011) has only a single reference to Christianity.

${ }^{3}$ Fénelon Archbishop of Cambray, chose to describe the Hellenes for their instructive value. Lives of the Ancient Philosophers (New York, 1900). 
of the ordinary people. ${ }^{4}$ For the curious reader, especially in an age when we are intermittently gripped by Luxury Fever, ${ }^{5}$ it may be interesting to note that the hardest ethic to accept in a Christian society has been that legitimizing consumption.

I have chosen here a simpler path. Are there questions where the issue can be decided by arithmetic? Intellectual priorities for several modern ideas can be determined by dates and by the public impact. If Anglican Christians have the priority in several such instances, then perhaps the rest of the case is not hopeless. I will make the case below using the topic of economic growth, and the impediments to the spread of such growth from Europe to the rest of the world.

Why are the Anglicans particularly important for my thesis? First, because Britain led the world into the Industrial Revolution, a point that needs no elaboration. Secondly, because the Anglican clergy were generally well educated, with the clerical hierarchy containing many intellectuals notable in their own right. Such education provides the ability to respond to social change; more importantly, the clergy believed in Christianity as intellectually equal to facing any intellectual challenge, which led David Hume to once refer to Christianity as a 'philosophical superstition. ${ }^{6}$ Hence the Anglican clergy repeatedly entered the fray, especially where the well-being of their flock was concerned. The period I will cover is the eighteenth century, which has become popularized as the 'Enlightenment.' One feature of the Enlightenment was its claim that people should forget about the afterlife and concentrate on being happy here on earth. But how? If worldly wealth made people happier, then, as I will show, it was the clergy who were most active in promoting the wealth of the poor.

A further reason for focusing upon Britain is that there are plenty of primary materials - in English, the only language I read with some ease. It is very important to realize, and practically impossible to appreciate, just how crucial primary materials are for such historical study. When we approach the lives of those who lived in earlier times, the primary goal

\footnotetext{
${ }^{4}$ My colleague, Edward McPhail, and I are working on a paper called 'Golden Rule vs Greatest Happiness', a title inspired by Lord Macaulay's review of Jeremy Bentham's utilitarian prescriptions, where Macaulay stated that Britain did not need the Greatest Happiness principle because it already possessed the Golden Rule from Christianity.

${ }^{5}$ The title of a relevant and readable book by Robert Frank (Free Press, 1999).

${ }^{6}$ And especially pernicious therefore.
} 
must not be to praise or blame, but to understand. Only after we have tried to see the world through 'their' eyes, should we try to evaluate. Such understanding can only be obtained by trying to see the world as the people we are studying saw the world. Primary sources allow us to enter the minds of those we read.

'Knowledge,' in the abstract, does not exist. Just as cultures fade away unless they are remembered and exercised, so too knowledge withers away. Knowledge has to be recognized, filtered, preserved, transmitted, reframed, and retransmitted. All these acts need resources-who will commit the time, energy and money? So if something is now 'common knowledge,' we have also to ask-in whose interest did this knowledge arise and awaken? For almost fifty years I have been astonished at the limited understanding in the West of the Christianity I will speak of. Primary sources are the most, perhaps the only, authoritative source for 'disputed' issues; they are also the only way to uncover 'buried' issues e.g. how would one know by reading the webpage of the European Union that the most active founders of the EU were inspired by their own liberal Catholicism? ${ }^{7}$

${ }^{7}$ Due to space limitations, I have had to choose between giving references for my general thesis or for my specific illustrations. Since my own papers have covered the specific issues in more detail, I have chosen to give references mostly for the general thesis about Christianity. This is unfair to many scholars and I apologize in advance. The references are as follows. Rashid, Salim, "Richard Whately and Christian Political Economy at Oxford and Dublin," Journal of the History of Ideas, Vol. I (1977), 144-155. Rashid, Salim, "Richard Whately and the Struggle for Rational Christianity in the Mid Nineteenth Century," Historical Magazine of the Protestant Episcopal Church, Vol. 47 (September 1978), 293-311. Rashid, Salim, "Richard Jones and Baconian Historicism at Cambridge," Journal of Economic Issues, Vol. 8 (March 1979), 159-176. Rashid, Salim, "Anglican Clergymen-Economists and the Tithe Question in the Mid Nineteenth Century," Journal of Religious History, Vol. 11 (Fall 1980), 64-76. Rashid, Salim, "He Startled as If He Saw a Spectre: Josiah Tucker's Proposal for American Independence," Journal of the History of Ideas, Vol. 43 (July 1982), 439-460. Rashid, Salim, "Josiah Tucker, Anglican AntiSemitism, and the Jew Bill of 1753," Historical Magazine of the Protestant Episcopal Church, Vol. 51 (June 1982), 191-201. Rashid, Salim, "Christianity and the Growth of Liberal Economics," Journal of Religious History, Vol. 12 (1982), 221-232. Rashid, Salim, "The Clergymen-Scholars of Economic Development," This World, no. 5 (Spring 1983), 94-106. Rashid, Salim, "The Irish School of Economic Development: 1720-1750," The Manchester School of Social and Economic Studies, Vol. LVI, no. 4 (December 1988), 345-369. Rashid, Salim, "Berkeley's Querist and Its Influence," Journal of the History of Economic Thought, Vol. 12 (Spring 1990), 38-60. Rashid, Salim, "Christianity and Economics: Is There A Lacuna?" Anglican and Episcopal History, Vol. LX, no. 1 (March 1991), 25-42. Rashid, Salim, "Jonathan Swift, Wood's Halfpence and Anglican Passive resistance," unpublished. 


\section{Three Remarkable Men: Berkeley, Swift, ANd Tucker}

I will present the most salient aspects of the economic thoughts of three eighteenth-century Anglican clergymen, George Berkeley, Jonathan Swift, and Josiah Tucker. While Berkeley is well-known as a philosopher, and Swift is even more famous as the author of Gulliver Travels, Tucker is practically forgotten today, even though in his times he was probably more in the news than either of the other two. Berkeley provided a complete and convincing theory of economic development, framed with Ireland in mind. Swift considered English rule of Ireland to be oppressive and argued for passive resistance as the only path open in the face of overwhelming force; he rebelled at the thought that Ireland was being sold out to the English and saw the need for 'nationalism' in the Irish to further their development. Tucker was convinced that War for the sake of Trade was unchristian, and spent some thirty years showing why rich countries need not fear the growing riches of poor ones, so they should not consider force as a solution for any international economic problems.

Two of the three clergymen, Berkeley and Swift, were Anglo-Irish, and with good reason. Ireland was the first 'colony' of Europe, so it was natural that their experience would adumbrate later events. Ireland was originally annexed to England by conquest and its subordination to London was reinforced by the wars of the 1690s. An army of around 12,000 regular soldiers kept the peace, which was administered by the appointment of Englishmen to high political and ecclesiastical office, and the control of Irish legislative decisions through Poynings's Law of 1495 (not repealed until 1782) and the Declaratory Act of 1720. Anglo-Irish formed the top of the Irish pyramid, followed by Scot Presbyterians and the native Irish Catholics (and the dissenters) were constrained by Penal Laws. England regarded Ireland as a colony. What is notable is that the revolt against the English was led by members of the Anglo-Irish elite. William King, Archbishop of Dublin and the most determined proponent of the Irish 'nation,' expressed the Irish position best ${ }^{8}$ : 'Our payments are like the fleecing of sheep, of which they have no benefit, but must prepare a new growth out of their bodies or remain naked'.

George Berkeley is known today as the Philosopher of immaterialism and as a Christian apologist. Even at a young age, his idealism struck

${ }^{8}$ King to Addison, August 25, 1715. 
those whom he met. It was this idealism that led him to project a College in the Bermudas, which would serve for the Christian regeneration of the New World. He left for Rhode Island with the hope of creating a purer society in the New World. The funds he was promised to start his venture never came, so he returned to Britain and was exiled to Cloyne, perhaps the poorest diocese in Ireland. Dedicating himself to the poor upon reaching Cloyne, Berkeley wrote the most philosophical treatise on economic development yet written-the Querist. The style is strange, in that the entire pamphlet consists of queries, appropriate words from one who is the Querist, until one realizes that every question posed is rhetorical and carries its own answer. To those who asked why a clergyman would write on economics, Berkeley said, in the introduction to the second edition of the Querist 'To feed the hungry, and clothe the naked, by promoting an honest industry, will perhaps be deemed no improper employment for a clergyman who still thinks of himself a member of the commonwealth.' Berkeley was praised by many contemporaries-by the Scots Robert Wallace, Lord Lauderdale, Dugald Stewart, and the English poets Robert Southey and Samuel Taylor Coleridge. Alexander Pope said of him, 'To Berkeley, every virtue under heaven.'

Jonathan Swift took holy orders in 1695 and soon thereafter came to the attention of the Archbishop of Dublin, William King, mentioned earlier. King sent Swift to London to canvass for the First Fruits, which would augment the income of the Irish Anglican church. Swift's literary abilities made him many friends in London and he soon came under the eye of the Tory politicians and used his pen to serve Tory purposes. With the fall of the Tories and the change of monarch from Queen Anne to King George I, Swift rapidly fell from grace and went back into 'exile' in Ireland. King again cultivated Swift and when the English sliced off the independence of the Irish Parliament, the two began to think of systematic opposition. Swift began, in 1720, with a pamphlet which carried the memorable message, 'Burn everything English, except their people and their coals.' When the English tried, in 1722 , to introduce a new halfpenny coin by giving the monopoly of it's production and distribution to William Wood, an Englishman, Irish anger boiled over. A boycott of the new coin was successfully organized-quite remarkable in view of the fact that much money within Ireland was circulated by the army, and refusing their expenses could grind everyday activity to a halt. Passive resistance, a form of civil disobedience, had been pioneered earlier by Archbishop Sancroft and the non-jurors; Swift extended it into ordinary politics. What 
Swift hoped to do was to galvanize the Irish elite into standing united as 'nationalists' against the English.

Josiah Tucker began his clerical career as chaplain to Bishop Joseph Butler, then analyzed the strengths and weaknesses of the English and French comparative economies 1750, Even at this early stage he appreciated immigrants.

What! must Foreigners, and we know not who, come and take the Bread out of our Mouths?... Let us see therefore in the next Place, Out of whose Mouths' do they take this Bread? If they introduce new Manufactures, or carry those already established, to greater Perfection, in that Case the Publick' is greatly benefited, and no Individual can be injured. ${ }^{9}$

It is no surprise that Tucker next wrote as a supporter of the Naturalisation of Foreign Protestants in 1753, then of the Naturalisation of Jews in 1754. The liberal bent of the Anglican hierarchy can be seen from the fact that Tucker was appointed tutor to the Prince of Wales in 1756. The Seven Years War turned him against all wars for the sake of trade and led to a pamphlet, The case of Going to War for the sake of Trade in 1763. In 1767, he suggested that the Americans were planning independence while protesting loyalty. Tucker's solution was to set the Americans free. He vigorously opposed war against the Americans; while Tucker's arguments gained an appreciation, they were unpopular, so Tucker began calling himself 'Cassandra' because of the derision and neglect he aroused. Tucker's formulation of the role of self-interest has rarely been bettered and was approvingly quoted by libertarians. Tucker unhesitatingly ascribes secular happiness to self-love and then asks what role reason has to play. ${ }^{10}$

Not surely to extinguish self-love; that is impossible. And it might be questioned whether it would be right to attempt even to diminish it. For all arts and sciences, and the very being of arts and commerce, depend upon the right exertion of this vigorous and active principle... Consequently, the main point to be aimed at, is neither to extinguish nor enfeeble self-love, but to give it a direction, that it may promote the public interest by pursuing its own. And then the spirit of monopoly will operate for the good of

${ }^{9}$ A Brief Essay on the Advantages and Disadvantages which Respectively Attend France and Great Britain, with Regard to Trade: With Some Proposals for Removing the Principal Disadvantages of Great Britain. In a New Method. Josiah Tucker T. Trye (1750), p. 85.

${ }^{10}$ Shelton (1981), pp. 91-92. 
the whole.....and if this is the proper business of reason. Divert therefore the pursuits of self-love from vicious or improper objects, to those that are commendable and virtuous.

\section{GeOrge Berkeley}

Berkeley was but one of many who tried to comment and prescribe for Ireland between 1680 and 1740. Although space will only permit consideration of Berkeley and Swift, those who elaborated upon the ideas stated below all took Christianity seriously, hence their relevance to this paper. Berkeley made two fundamental contributions. First, he provided the first definition of development that explicitly included all the people:

- 'Whether a people can be called poor, where the common sort are well fed, clothed and lodged?'

- 'Suppose the bulk of our inhabitants had shoes to their feet, clothes to their backs, and beef in their bellies, might not such a state be eligible for the public, even though the squires were condemned to drink ale and cider?'

Note how equity is written into the definition of development by Berkeley. This is also the major change in view that took place after WWII.

Berkeley's second major contribution lay in clarifying how wealth arises, a crucially important task in an age when many were distracted by the acquisition of gold and silver.

- 'Whether the four elements, and man's labour therein, be not the true source of wealth?'

This was clarity, not originality. By the time Berkeley came to revise the Querist in 1743, he clearly noted that it is human capital that is the real fount of growth.

- 'Whether faculties are not enlarged and improved by exercise?'

- 'Whether the sum of the faculties put into act, or in other words, the united action of a whole people doth not constitute the momentum of a State?'

- 'Whether such momentum be not the real stock of a State?' 
- 'Whether in every wise State the faculties of the mind are not most considered?'

- 'Whether the momentum of a State doth not imply the whole exertion of its faculties, intellectual and corporeal; and whether the latter without the former could act in concert?'

I cannot over-emphasize how important Berkeley's contribution is. The most important economic fact post WWII is that demonstrated by the East Asian economies-7\% per capita growth is achievable. It is a growth rate that doubles income every 10 years so if one starts with 10,000 at age 20 , one retires with 160,000 at age 60 . It means the end of poverty in one lifetime. The factor that has contributed most to such growth and forced its attention upon the profession is human capital. So Berkeley is twiceblessed; in defining development and in focusing upon its most important cause. $^{11}$

As this paper is dealing only with concepts like wealth, growth and the distribution of wealth-what economists like to call 'real' variables, to distinguish them from 'monetary' ones like money supply and pricesit is well to remember that both Berkeley and Swift made notable contributions to money and finance. Swift began the Irish loan fund with the first 500 pounds he saved. This was then loaned out to those who could provide a character reference. Swift provided what has come to be known as micro-credit, with the condition that one needed a reference who provided a 'character collateral' instead of a peer group which accepted responsibility for the loan and provided an alternative monitoring mechanism for the loan. While the rich must always have given 'collateral free' loans to the poor, Swift's Loan Fund is the earliest institution to provide micro-credit. Berkeley urged upon his contemporaries the view that money was only a ticket, a counter, which was useful in creating and circulating real wealth. While this was a minority view at that time, Berkeley's pithy presentation gave it much clarity and force. Berkeley insisted

${ }^{11}$ To be fair to the Irish school, a few words on the general program. What can be done within the market? The wealthy must encourage and appreciate Irish products; housing, painting, etc. The poor must acquire a taste for riches, this will elevate their standards and make them willing to work hard. Absentees who stayed abroad but lived off Irish revenues should learn to accept their responsibilities in Ireland. When government will not help, form a voluntary society to propagate your goals-the Dublin Society; in modern parlance, the first NGO. 
that the primary policy tool was a proper monetization of the economy. While many others had seen the utility of a bank, it was Berkeley who wanted to create one which functioned for the benefit of the public, and not for private profit alone. He left his bishopric at Cloyne and spent a year in Dublin to try and convince the Irish Parliament to authorize a national Bank, complete with instructions for a constitution. Failure seems to have embittered Berkeley and he never again tried to initiate policy changes so directly; he even removed all the queries relating to the bank in a revised edition of the Querist. Berkeley not only espoused a national bank, but he also had the prescience to see that a National Debt can serve to stabilize the entire monetary system.

- Whether the credit of the public funds be not a mine of gold to England?

- And whether any step that should lessen this credit ought not to be dreaded?

- Whether such credit be not the principal advantage which England hath over France? I may add, over every other country in Europe.

- Since the monetization of the National Debt was perhaps Britain's most significant financial innovation in this century, Berkeley deserves more credit for his insight.

\section{JoNATHAN SWIFT}

The agitation that marked the 1720s in Ireland began when the patent to coin halfpence was granted to an Englishman, William Wood. The Irish felt this was a ruinous change and united against the measure. Such unity took the English administration quite by surprise. The unity was largely forged by the prose of Jonathan Swift, who posed as a Drapier and wrote the famous Drapier's Letters, to arouse and unite Irish opposition. The plan was to unite in refusing to accept the new coin-seemingly impossible, but it succeeded, and Swift hereafter forever linked with the cause of liberty for Ireland. The Drapier's Letters make for poor economics, and Swift's genius lay in writing in popular language and using such arguments as would arouse Irish enthusiasm for the boycott. In the midst of the debates, Swift wrote a self-conscious sermon about passive resistance 
which needs appreciation. He was almost certainly influenced by Archbishop Sancroft, who had earlier grappled with the question 'How does one respond to overwhelming force?'

Sancroft's life and career were full of contrary events. As a royalist, Sancroft believed kings were appointed by God, so the beheading of Charles I meant that he had to transfer his loyalty to Charles II. So he lived in exile, so to speak. Upon the Restoration of Charles II, Sancroft was rewarded with desirable church appointments and rapid promotions, leading from the Deanery of St Paul's in 1664 to the Archbishopric of Canterbury in 1677. When Charles died, James II was crowned by Sancroft himself. As James II began his policy of favoring Catholics, Sancroft found himself torn between his loyalty to his King and his loyalty to the Anglican church. When proclamation of the Declaration of Indulgence was required by James in 1687, Sancroft and six other bishops petitioned the King. This was viewed as an act of rebellion and James imprisoned the seven bishops. Exercising the right to petition was a form of democratic disobedience. Despite the imprisonment, five of the seven bishops remained loyal to James even after James fled upon the arrival of William and Mary. Sancroft, eight other bishops, and 400 members of the clergy, refused to take the oath of allegiance to William and Mary and were known as the non-jurors. They were all fired from their posts and largely slipped into out of the history books. Faced with a choice between their conscience and their positions, the non-jurors sacrificed all worldly ambition. Not a few or a dozen or even a hundred but four hundred did so. The Anglican church pioneered passive resistance in the petition to James, loyalty in the face of imprisonment and the refusal to take the oath of loyalty to William and Mary.

The sermon, 'Doing Good,' was delivered in 1724 , at a time when Swift was working very hard and taking a considerable risk to keeping Irish resolve united in rejecting the new coinage of Wood. ${ }^{12}$ How could the Irish obtain a complete repeal of Wood' halfpence? The sermon provides a map of the intellectual challenges in organizing movements of passive resistance. Swift begins by noting the pervasive power of self-interest, but does not consider it to be ill; rather, and surprisingly, Swift takes selfinterest to be a directive of the Creator. 'The law of nature, which is the

${ }^{12}$ Swift, Jonathan, 'Doing Good,' in Herbert Davis (ed.), The Prose Works of Jonathan Swift, Vol. 9 (Basil Blackwell, Oxford, 1955 [1724]), pp. 232-240. As the sermon is short, I have avoided page references for readability. 
law of God, obligeth me to take care of myself first.' This self-love is commonly meant to extend to one's neighbors, as is well-known. Swift has to motivate hundreds of thousands, not to avoid the market, or even be selective in what to trade or consume, or wear, but only to refuse Wood's Halfpence as payment for any trade-all other coin was fine. So he develops the theme that undergirds his subsequent argument-small sacrifices by me which enable great gains for my neighbor become duties incumbent upon me. 'But if, by a small hurt and loss to myself, I can procure a great good to my neighbor, in that case his interest is to be preferred.'

Swift has rehearsed a well-known point about loving our neighbor, but immediately extends it to a political context by referring to 'our neighbor in a public capacity' which is but another way of referring to one's fellow citizens.

there is yet a duty of a more large extensive nature incumbent on us; which is, our love to our neighbour in his pubic capacity, as he is a member of that great body the commonwealth, under the same government with ourselves; and this is usually called love of the public, and is a duty to which we are more strictly obliged than even that of loving ourselves; because therein ourselves are also contained, as well as our neighbors, in one great body. (p. 233)

Swift continues with the point that it was this love of the public that was termed 'virtue' by Hellenes and Romans.

Swift then lists three reasons why this duty to the public is so strongly binding, before going on to elaborate why they are important and how individuals can display such virtue.

First, that there are few people so weak or mean, who have it not sometimes in their power to be useful to the public....

Secondary, That it is often in the power of the meanest among mankind to do mischief to the public.

And, lastly, that all willful injuries done to the public are very great and aggravated sins in the sight of God. (pp. 113-114)

It is the second point that requires close attention because Swift has to persuade thousands of poor shopkeepers and peasants that they must continue to refuse the new coin-none of them must feel that their individual actions are too insignificant to matter, hence to follow their own convenience and accept the coin. Swift insists that even the meanest can do 
mischief, and then notes the importance of such actions as the principal source of public misfortune. 'it is often in the power of the meanest among mankind to do mischief to the public. And hence arise most of those miseries with which the states and kingdoms of The earth are infested.' (p. 116). Swift gives a recent economic example from the cloth trade, where the bad wares of some had hurt the trade of all, to bring home the force of such behavior '... we now find by experience, that the meanest instrument may, by the concurrence of accidents, have it in his power to bring a whole kingdom to the very brink of destruction' Swift jumps from the cloth trade to coin without any warning and claims that the same selfishness is still 'endeavouring to finish his work; and hath agents among ourselves, who are contented to see their own country undone, to be small sharers in that iniquitous gain, which at last must end in their own ruin as well as our.'

In the analytical language of economics, Swift was dealing with a public goods issue. ${ }^{13}$ Everyone would gain from a good currency, but no one individual would have an incentive to maintain the monetary system since his own gain or loss was infinitesimal compared to the aggregate.

Every man is upon his own guard for his private advantage; but, where the public is concerned, he is apt to be negligent, considering himself only as one among two or three millions, among whom the loss is equally shared, and thus, he thinks, he can be no great sufferer.

This prescient statement was followed by the recognition that material self-interest alone was inadequate to prevent an ill outcome; what was needed was a sense of concern for the public, thus harking back to the principle that he had established earlier-enduring a small harm becomes a duty if great good can be thereby attained.

Against which there can be no defence, but a firm resolution in all honest men, to be closely united and active in shewing their love to their country, by preferring the public interest to their present private advantage.

13 The public goods argument of Swift is also highlighted in McPhail-Rashid (2012). McPhail, Edward, and Salim Rashid, "Swift and Berkeley on Economic Development," in T. Boylan, R. Prendergast and J. Turner (eds.), A History of Irish Economic Thought (Routledge, London, 2010), pp. 32-55. 
There are two ordinary acts which can prove to be very harmful-the spreading of rumors and making false accusations. Swift singles these out for attention, since either can cause the will of the people to falter, and warns his hearers not to indulge in either. There is no evidence that the sermon itself was effective in arousing further opposition to Wood's Halfpence. ${ }^{14}$ That was the function of the Drapier's Letters. Rather, the sermon tells us how Swift thought about this unusual obligation and how he rationalized his activity with his role as pastor. Swift was greatly moved by Sancroft and when the English tried to force Wood's halfpence on the Irish, he willingly put his talents to work in arousing public noncooperation.

To Swift, this was the beginning of a more persistent rejection by the elite of the plums given by the English to keep Irish separatist tendencies in check. Why does this matter? Because simple accumulation in a poor country normally leads to the flight of the rich. As all the good things of life are more available in rich countries, even more so the opportunities for the talented, those who are rich or talented in a poor country will be tempted to leave home and migrate. However, understandable such mobility of brains and capital may be, it necessarily drains the poor country. Something must hold you to your country. This something cannot be material comfort, because, by assumption, you are a poor country. A simple way to describe this immaterial glue which keeps talent at home is 'Nationalism.' Developing countries have produced many heroic figures who could have easily made much money by migrating-Lee Kuan Yew of Singapore is a recent example-yet chose to stay at home because they believed in developing 'their' country. ${ }^{15}$ The flight of talent is perhaps the single greatest problem facing economic development today. Swift understood the problem and tried to mold Irish Nationalism with his writings.

${ }^{14}$ The awareness that in using the pulpit, Swift risked arrest and trial, comes out in one of his last sentences. 'And this, I am sure, sure, cannot be called meddling in affairs of state.' How Swift could claim that, after months of public struggle between the Westminster, the Lord Lieutenant and the Irish Parliament, the question of Wood's halfpence 'cannot be called meddling in affairs of state' must be left one's imagination. It was fortunate for Swift that the sermon was not widely noticed.

${ }^{15}$ Per contra, those poor countries whose leaders have concentrated on building their bank balances, despite the immense resources the poor countries possess, have stagnated in poverty. 


\section{JOSIAH TUCKER}

Josiah Tucker was born in 1713, graduated from Oxford, and took holy orders in 1736. In 1737 Bishop Joseph Butler urged Tucker to write a critique of Methodism, which may have led to Tucker's promotion to the rectorship of St Stephen's, Bristol, in 1749. Tucker wrote next to a widely read pamphlet comparing and contrasting the British and French economies. In subsequent years he argued vigorously for the value of immigrants and defended foreign protestants and then Jews. These writings led Bishop Hayter of Norwich to ask Tucker to compose a book on Commerce for the edification of the Prince of Wales, the future George III. This just as the Seven Years War began. Tucker's liberal and pacific ideas found no home. The stupendous victories of Britain in the Seven Years War led Tucker to venture with a pamphlet asking whether there could be a case for going to war for the sake of trade. Bitter about the public adulation for the victorious Pitt the Elder, Tucker exclaimed: 'Heroism is the wish and envy of all Mankind...let a Prince but feed his subjects with the empty diet of military fame, it matters not what he does besides...' The basis of Tucker's objection was that a benevolent God would not have created a world where mutual prosperity was incompatible with peace.

- 'Do the inhabitants of two adjoining towns or counties believe that they have an unalterable enemity with each other? Or do they believe that the Government they live under can ensure that the good of one is also the benefit of the other?'

- 'If therefore this is the case with respect to human Governments ...how then comes it to pass, that we should ascribe so much Imperfection, such Want of Benevolence, such Partiality, nay such premeditated Mischief to that great and equal Government, which presideth over all?’

The choice of the question and the nature of the solution were provided to Tucker by his faith-what then remained? To demonstrate the correctness of the conclusion through argument. Tucker got his chance when he pleaded that the American colonies should be left to go free-every colony had aspired to independence as soon as it was able to do so, it was only the Americans who protested loyalty even as they took steps to ensure independence. Do the Christian thing and, 'Let them go,' Tucker 
urged, so that we can become friends and Christians again. The political arguments do not concern us here, but the economic ones are worth noting, as they exemplify what it means to analyze a question of fact, what economists call 'positive' ones, while approaching the issue with faith, or what economists call a 'normative' approach.

In 1774 Tucker published Four Tracts, perhaps the best-selling of all his writings. He begins This is most evident in a later pamphlet developing the same theme, when Tucker argues that rich nations need never be overtaken by poor ones, provided they preserve their industry, ingenuity, and activity.

1. They have the advantage in institutions and infrastructure

2. They have the means and the capacity for inventing more

3 . They have the means to direct research more productively

4. Higher wages induce more exertion and invention

5. Riches permits a finer, more productive division of labor

6. The products of the rich, sold competitively, are cheaper and better

7. Capital is cheaper and more productive in a rich country.

Whether you agree or disagree, these are clear arguments. Bernard Semmel has demonstrated how they were influential in Parliamentary debates on Ireland in the 1770s. ${ }^{16}$ Tucker does not rest on general propositions. In Tracts 2 and 3, Tucker lays out his proposal for separation and its benefits. He applies his ideas to the American colonies, since it was widely feared that the loss of the colonies would be ruinous to British commerce. Tucker argued that since 'trade is not carried on for the sake of friendship, but of interest,' it only remained to ask where the interest of the colonists would lie after independence. Commodity after commodity is examined, and Tucker carefully points out how Britain would remain the best market for the colonists. Pitch, Tar and Naval stores, then Pipestaves and Lumber, then Rice and Tobacco and so on. The beginning of Tucker's reply to the Rice and Tobacco will sufficiently illustrate his method.

\footnotetext{
${ }^{16}$ Semmel, Bernard, The Rise of Free-Trade Imperialism (Cambridge University Press, Cambridge, 1970).
} 
[Objection] In case of a Separation, from whence shall we procure Rice and Tobacco? Answer 1: This objection turns on two suppositions, viz l. That after a Separation, the Virginians and Carolinians will not sell Tobacco and Rice to English merchants, for a good price, and ready money; and 2dly, that Tobacco and Rice can grow in no part of the Globe, but in Virginia and Carolina. Will any man in his senses affirm either of these things?

So independent was Tucker that he irritated both Court and Opposition. But he did not care. Just a fifth tract was in the press, Tucker heard about the defeat of Cornwallis, and placed a postscript: 'I am at a loss what to say on this occasion. To congratulate my country on being defeated is contrary to that decency which is due to the public. And yet, if this defeat should terminate in a total separation from America, it would be one of the happiest events that has ever happened to Great Britain.'

Tucker was read by many influential scholars and politicians. Bernard Semmel has shown how the ideas of Tract 1 were to be the foundation of what has been called 'Free Trade Imperialism'-the use of free trade for colonizing ends, an end that was never Tucker's aim! Dr. Samuel Johnson said of Tucker that 'No person, however, learned, can read his writings without improvement'; while John Wesley was led to reverse his initial stand against the Americans and for war. In June 1775, he had supported subduing the colonies but by December he wrote 'But I say as Dean Tucker, "Let them drop."”

\section{Conclusion-What Price Ignorance?}

Berkeley, Swift and Tucker covered some of the principal issues facing both developed and developing countries. But this by no means indicates the overall impact of Christian social thought. Richard Whately was the most effective popularizer of free markets in the nineteenth century; if we turn to policy, Bishop Fleetwood on Index Numbers and Henry Thornton on Banking come readily to mind; on the wider field of social economics, the Rev. Richard Jones is a major nineteenth-century figure. Churchmen were active in all forms of social reform such as the reform of prisons (Howard), the relief of debtors (Oglethorpe and Hanway) or slavery (Wilberforce). The critical role of Anglicanism persists in importance even as we cast a wider net. From the time when the judicious Hooker pleaded for a religion that possessed both richness and structure, to the efforts of many Christians to further science and innovation, to the 
philosophical acumen of Cudworth, Clarke, and King, there is a continuous chain of Anglican engagement on all issues concerning society. One cannot begin to penetrate the life of England without facing Anglicanism.

If Christians have been continuously engaged with the financial and monetary aspects of everyday life, why has the relevance of Faith and Finance not been more prominent? Every age has a 'climate of opinion' and Carl Becker explained well its importance when treating the philosophes. ${ }^{17}$

Whether arguments command assent or not depend less upon the logic that conveys them than upon the climate of opinion in which they are sustained. What renders Dante's argument or St Thomas' definition meaningless to us is not bad logic or want of intelligence, but the medieval climate of opinion---those instinctively held preconceptions in the broad sense, the Weltanschauung or world pattern...To understand why we cannot easily follow Dante or St Thomas...it is necessary to understand...the nature of this climate of opinion.

This climate of opinion decides the content of the possibilities open to us, and as Herbert Butterfield noticed, it is the greatest obstacle to appreciating the importance of Christianity. ${ }^{18}$

Certain characteristic notions have become prevalent concerning the past, certain views about the process of things in time, and certain impressions ...of the panorama of the centuries... is in reality a more serious obstruction to Christianity than the natural sciences.

Anyone who has bothered to read the literature produced by and for everyday folk cannot fail to be impressed by the depth and intensity of Christian devotion present throughout society. It strains all credulity to accept the insignificance of these acts of piety in creating a society where certain virtues were widely approved and corresponding vices discouraged.

${ }^{17}$ Becker, Carl, The Heavenly City of the Eighteenth Century Philosophers (Yale, New Haven, 1932), p. 5.

${ }^{18}$ Butterfield, Herbert, Christianity and History (Collins, Fontana, London, 1957), p. 13 . 
Some authors, such as Jacob Viner, ${ }^{19}$ have striven hard to be fair, and Viner's writings provide some of the best clues on sources and issues. But such fairness has not been the norm. whether it be by the selection of material, or by their treatment of those selected, the Christian contribution has been presented as the 'opposition' to 'modernity.' In Peter Gay's widely acclaimed The Enlightenment, has the significant subtitle, 'The Rise of Modern Paganism,' which clarifies why the light was needed. It was to lead Europe away from the darkness of Christianity and the fears of a future life. In the early pages, Gay feels some scholarly pangs about the singularity of his heroes ${ }^{20}$

As I shall show over and over again...ideas and attitudes generally associated with atheistic, subversive philosophes...were the common property of most educated men in the eighteenth century...the war they [the philosphes] fought was half won before they joined it.

Not only is this claim of fighting a war half done poorly documented in what follows, Peter Gay failed to ask about those questions which were either ignored by the philosophes or where they fell behind their Christian contemporaries. The victory of such partial scholarship has been so total that, upon hearing William Temple lament the lack of Christian involvement with economics, Lord Keynes had to remind the Archbishop of Canterbury about the reality of Christian economic thought in the eighteenth century. Apart from Hume, Smith, Mandeville, Cantillon, and Bentham, Keynes said ${ }^{21}$ : 'I can think of no one important in the development of politico-economic ideas... who was not a clergyman, and in most cases a high dignitary of the Church.'

The extent of the misrepresentation of the role of Anglican Clergyman in promoting England's economic development is almost comical. The noted economic historian, R. H. Tawney, referring to the eighteenth century, said of the Anglican Church in the face of increasing wealth of

${ }^{19}$ Viner, Jacob, The Role of Providence in the Social Order: An Essay in Intellectual History (American Philosophical Society, Philadelphia, 1972). See also Viner, Jacob, "Religious Thought and Economic Society," in Jacques Melitz and Donald Winch (eds.), History of Political Economy, Vol. 10, No. 1 (Spring 1978).

${ }^{20}$ Gay, Peter, The Enlightenment: An Interpretation (Vintage Books, New York, 1968), pp. 22-23.

${ }^{21}$ Iremonger, F. A., William Temple (Oxford, Oxford University Press, 1948), pp. 438439. 
Britain that it did not give guidance because it had none to give. Tawney chooses Josiah Tucker as the embodiment of the new emptiness of Anglicanism. It is as though Capitalism, Riches and Wealth were necessarily immoral according to Tawney. Tucker, however, himself had met such attitudes and responded by expressing surprise at people who shouted 'Church in Danger' whenever any liberal economic measure were proposed. $^{22}$

I really think, the Church of England comes nearest to perfection of any since the Apostles days; and, under that persuasion, I confess it appears to me a most injurious Treatment, to be always representing her to be in a crazy, tottering Condition, ready to fall and never out of Danger.

Trapped between the omissions of its critics and the ignorance of its friends, Anglicanism has been hobbled. In the process, our capacity to understand the past has been numbed. Whether we agree or disagree with religion, there is little doubt that Christianity was the energy of the everyday lives of ordinary people in the West. In the words of Christopher Dawson, ${ }^{23}$

A Christian civilisation is certainly not a perfect civilization, but it is a civilization which accepts the Christian way of life as normal and frames its institutions as the organs of a Christian order. Such a civilsation actually existed for a thousand years, more or less. It was a living and growing organism---a great tree of culture which bore rich fruit in its season.

With this energy to rely upon, the civilization of the West was built.

\section{BIBLIOGRAPHY}

Becker, Carl. The Heavenly City of the Eighteenth Century Philosophers, 5. New Haven: Yale, 1932.

Butterfield, Herbert. Christianity and History, 13. Fontana, London: Collins, 1957.

${ }^{22}$ Tucker, Josiah, Reflections on the Naturalisation of Foreign Protestants (London, 1953), pp. 57-58.

${ }^{23}$ Dawson, Christopher, The Historic Reality of Christian Culture (Harper, New York, 1960), p. 36. For a longer and more eloquent statement of the point see Butterfield, op. cit., pp. 170-171. 
Dawson, Christopher. The Historic Reality of Christian Culture, 36. New York: Harper, 1960.

Fénelon, François. Lives of the Ancient Philosophers. New York, 1900.

Frank, Robert H. Luxury Fever. New York: Free Press, 1999.

Gay, Peter. The Enlightenment: An Interpretation, 22-23. New York: Vintage Books, 1968.

Iremonger, F. A. William Temple, 438-439. Oxford: Oxford University Press, 1948.

McPhail, Edward, and Salim Rashid, "Swift and Berkeley on Economic Development." In A History of Irish Economic Thought, edited by T. Boylan, R. Prendergast and J. Turner, 32-55. London: Routledge, 2010.

Rashid, Salim. "Richard Whately and Christian Political Economy at Oxford and Dublin." Journal of the History of Ideas 38 (1977): 144-147.

Rashid, Salim. "Richard Whately and the Struggle for Rational Christianity in the Mid Nineteenth Century." Historical Magazine of the Protestant Episcopal Church 47 (September 1978): 293-311.

Rashid, Salim. "Richard Jones and Baconian Historicism at Cambridge." Journal of Economic Issues 13 (March 1979): 159-176.

Rashid, Salim. "Anglican Clergymen-Economists and the Tithe Question in the Mid Nineteenth Century." Journal of Religious History 11 (Fall 1980): 6476.

Rashid, Salim. "Christianity and the Growth of Liberal Economics." Journal of Religious History 12 (1982): 221-232.

Rashid, Salim. "He Startled as If He Saw a Spectre: Proposal for American Independence." Journal of the History of Ideas 43 (July 1982): 439-460.

Rashid, Salim. "Josiah Tucker, Anglican Anti-Semitism, and the Jew Bill of 1753." Historical Magazine of the Protestant Episcopal Church 51 (June 1982): 191-201.

Rashid, Salim. "The Clergymen-Scholars of Economic Development." This World, no. 5 (Spring 1983): 94-106.

Rashid, Salim. "The Irish School of Economic Development: 1720-1750." The Manchester School of Social and Economic Studies LVI, no. 4 (December 1988): 345-369.

Rashid, Salim. "Berkeley's Querist and Its Influence." Journal of the History of Economic Thought 12 (Spring 1990): 38-60.

Rashid, Salim. "Christianity and Economics: Is There a Lacuna?" Anglican and Episcopal History LX, no. 1 (March 1991): 25-42.

Rashid, Salim. "Jonathan Swift, Wood's Halfpence and Anglican Passive Resistance." Presented at ASECS meetings in Los Angeles, 2015.

Rose, David. The Moral Foundation of Economic Behavior. Oxford: Oxford University Press, 2011. 
Semmel, Bernard. The Rise of Free-Trade Imperialism. Cambridge: Cambridge University Press, 1970.

Swift, Jonathan. 'Doing Good.' In The Prose Works of Jonathan Swift, Vol. 9, edited by Herbert Davis, 232-40. Oxford: Basil Blackwell, 1955 [1724].

Tucker, Josiah. Reflections on the Naturalisation of Foreign Protestants, 57-58. London, 1953.

Viner, Jacob. The Role of Providence in the Social Order: An Essay in Intellectual History. Philadelphia: American Philosophical Society, 1972.

Viner, Jacob. "Religious Thought and Economic Society." In Jacques Melitz and Donald Winch (eds.), History of Political Economy 10, no. 1 (Spring 1978).

Open Access This chapter is licensed under the terms of the Creative Commons Attribution 4.0 International License (http://creativecommons.org/licenses/ by $/ 4.0 /)$, which permits use, sharing, adaptation, distribution and reproduction in any medium or format, as long as you give appropriate credit to the original author(s) and the source, provide a link to the Creative Commons license and indicate if changes were made.

The images or other third party material in this chapter are included in the chapter's Creative Commons license, unless indicated otherwise in a credit line to the material. If material is not included in the chapter's Creative Commons license and your intended use is not permitted by statutory regulation or exceeds the permitted use, you will need to obtain permission directly from the copyright holder.

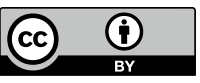

